\title{
The role of interdisciplinary cooperation in the prevention of Medication-Related Osteonecrosis of the Jaw (MRONJ)
}

\author{
Monika Teślak $\mathbb{D}^{\mathbb{D}}$, Izabela Chlebus $\mathbb{D}$, Iwona Ordyniec-Kwaśnica
}

${ }^{1}$ Department of Dental Prosthetics, Medical University of Gdańsk, Poland

\begin{abstract}
Medication-Related Osteonecrosis of the Jaw (MRONJ) is considered one of the most severe complications of treatment with antiresorptive drugs. The number of patients with MRONJ has significantly increased due to the broadening of the indication to treat with bisphosphonates and other antiresorptive drugs (e.g. denosumab). Because MRONJ has a significant impact on the patients' quality of life, it is necessary to reduce the risk of such complications by implementing preventive measures, e.g. full dental and oral cavity examination for all patients qualified for treatment with angiogenesis inhibitors or antiresorptive drugs.
\end{abstract}

Keywords: bisphosphonates $\cdot$ denosumab $\cdot$ osteonecrosis

\section{Citation}

Teślak M, Chlebus I, Ordyniec-Kwaśnica I. The role of interdisciplinary cooperation in the prevention of Medication-Related Osteonecrosis of the Jaw (MRONJ). Eur J TransI Clin Med. 2020;3(1):60-65.

DOI: 10.31373/ejtcm/120581

\section{Introduction}

Bisphosphonate-Related Osteonecrosis of the Jaw was described for the first time in 2003 in a case series of 36 patients treated with zoledronic or pamidronic acid [1]. The authors described painful exposure of the maxilla and mandible that did not react to surgical nor pharmacological treatment [1]. Numerous case reports of this condition were published since and its nomenclature has been changing [2-4]. Due to the increasing number of described cases of antiresorptive drug-related osteonecrosis of the jaw bones, in 2014 the American Association of Oral and Maxillofacial Surgeons (AAOMS) suggested the term Medication

Corresponding author:

Monika Teślak, Department of Dental Prosthetics, Medical University of Gdańsk, Poland

e-mail: monika.teslak@gumed.edu.pl

No external funds.

Available online: www.ejtcm.gumed.edu.pl

Copyright ${ }^{\circledR}$ Medical University of Gdańsk

This is Open Access article distributed under the terms of the Creative Commons Attribution-ShareAlike 4.0 International. 
Related Osteonecrosis of the Jaw (MRONJ) [4]. According to the current literature, osteonecrosis is a complication of treatment with bisphosphonates, denosumab and angiogenesis inhibitors [4-7].

\section{Diagnostic criteria of MRONJ}

The AAOMS position paper from 2014 indicate that MRONJ can be suspected if all of the following criteria are met:

- ongoing or past treatment with angiogenesis inhibitors or antiresorptive drugs,

- exposed facial/jaw bone or an extraoral fistula in the maxilla-facial area lasting $>8$ weeks,

- no previous history of head and neck radiotherapy,

- lack of metastases to the jaw bones [4].

Clinically, a patient with MRONJ may present with exposed jaw bone with a focus of necrosis, pathological fracture of jaw bone, pain, inflammation, tooth movement, extraoral fistula, oral antral or oral nasal communication [4, 8-9] [see Figures 1-3].

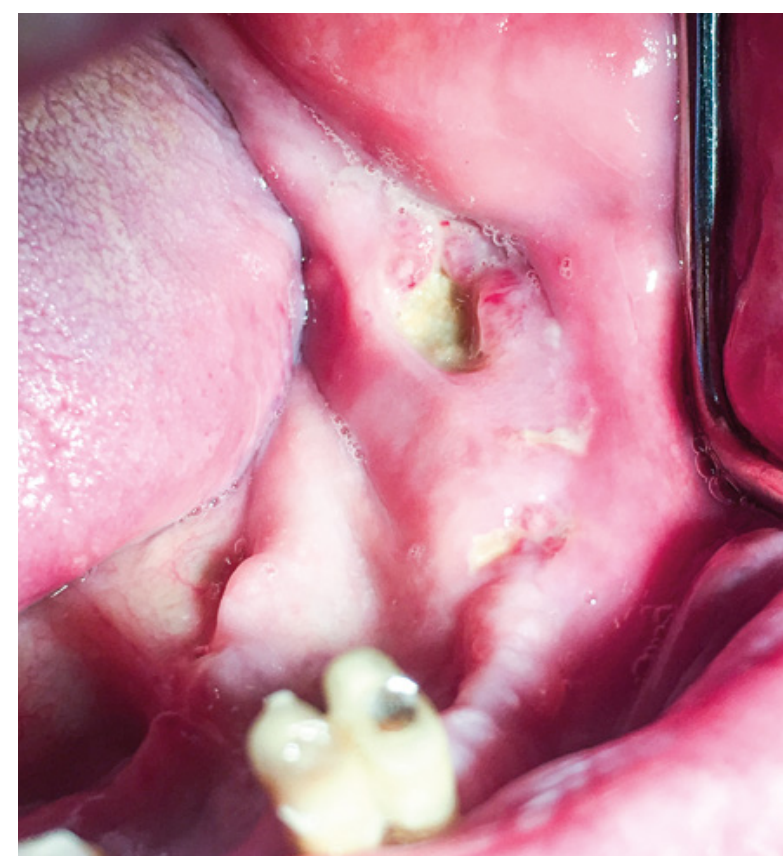

\section{$1 \mathrm{~A}$}

Because MRONJ is a relatively new diagnosis, the literature about its treatment is scant and often limited to case reports. Several national and international dental and maxillo-facial surgery associations published MRONJ treatment guidelines [4-7]. However, these guidelines are often divergent due to a limited number of treated patients and different institutional experience [10]. The treatment strategy suggested by the AAOMS seems to be useful as it is based on the assessment of MRONJ severity which then guides the decision about appropriate treatment [4, 6] [see Table 1]. Infection control, analgesia and stopping the progression of osteonecrosis are key elements of MRONJ treatment [6].

\section{Antiresorptive drugs}

Bisphosphonates are group of drugs indicated for osteoporosis, osteopenia, Paget's disease of the bone, osteogenesis imperfecta, prevention of hypercalcemia and metastasis to the bones [1, 3-4, 8, 11]. By binding to the bone matrix, bisphosphonates exert their antiresorptive activity at several stages, e.g. inhibition of osteoclast precursors' maturation, inhibition of matu-

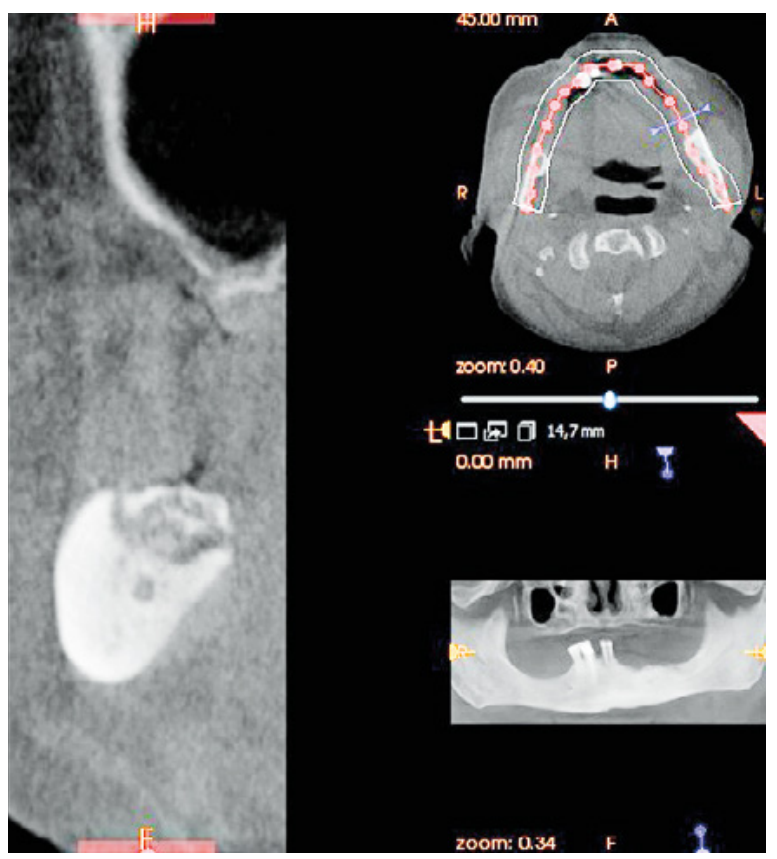

$1 \mathrm{~B}$

Figure 1. Example of Medication-Related Osteonecrosis of the Jaw.

A 75-year old male patient received $4 \mathrm{mg}$ zolendronic acid iv every month between XI 2018 - X 2019 as a treatment for prostate cancer

A. Multifocally exposed bone and purulence observed in the region of the left body of the mandible; the possible cause of MRONJ occurrence was unfitting partial denture in mandibula

B. Cone beam computed tomography showed excessive osteolysis in mandibular alveolar bone area 


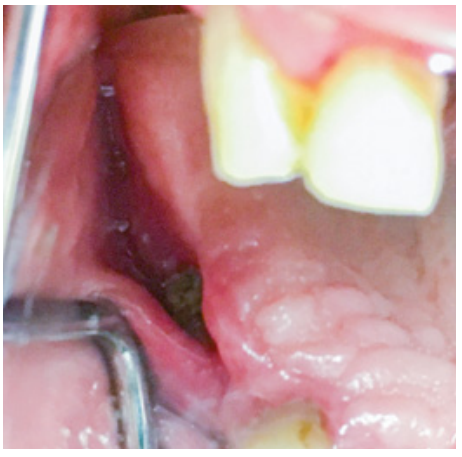

$2 \mathrm{~A}$

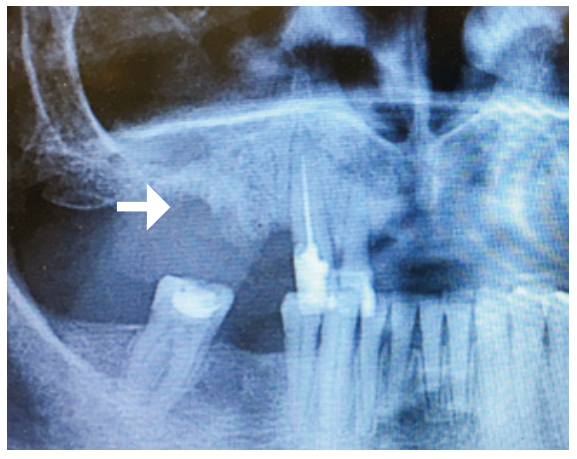

2 B

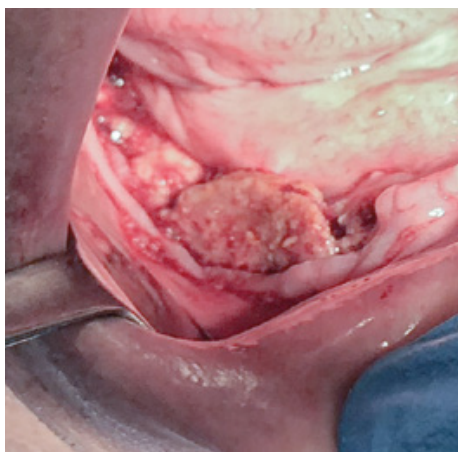

3

Figure 3. Example of Medication-Related Osteonecrosis of the Jaw. A male patient received $4 \mathrm{mg}$ zolendronic acid as a adjuvant treatment of multiple myeloma Exposed bone was observed in the right side of the mandibula; the possible cause of MRONJ occurence was extraction of teeth in above mentioned area.

photo source: author's own materials

Table 1. Treatment strategies according to the severity of MRONJ (modified from the 2014 AAOMS Guidelines)

\begin{tabular}{|c|c|c|}
\hline MRONJ STAGE & CLINICAL PICTURE & TREATMENT \\
\hline $\mathbf{O}$ & $\begin{array}{l}\text { Tooth or jaw pain without } \\
\text { a clinically noticeable cause, } \\
\text { tooth movement without } \\
\text { a clinically noticeable cause }\end{array}$ & $\begin{array}{l}\text { - Systemic treatment (antibiotics and analgesia), } \\
\text { - Referral to a dentist and follow-up visits } \\
\text { every } 8 \text { weeks, } \\
\text { - Patient education }\end{array}$ \\
\hline $\mathbf{I}$ & $\begin{array}{l}\text { Asymptomatic focal } \\
\text { bone necrosis } \\
\text { without inflammation }\end{array}$ & $\begin{array}{l}\text { - Antibacterial mouthwash, } \\
\text { - Follow-up visits every } 8 \text { weeks, } \\
\text { - Patient education }\end{array}$ \\
\hline II & $\begin{array}{l}\text { Focal bone necrosis } \\
\text { with symptoms } \\
\text { of inflammation } \\
\text { and significant pain }\end{array}$ & $\begin{array}{l}\text { - Systemic treatment (antibiotics and analgesia), } \\
\text { - Bone debridement to control the infection and } \\
\text { to reduce trauma from sharp bone fragments, } \\
\text { - Antibacterial mouthwash, } \\
\text { - Follow-up visits every } 8 \text { weeks, } \\
\text { - Patient education }\end{array}$ \\
\hline III & $\begin{array}{l}\text { Focal bone necrosis } \\
\text { with symptoms of inflammation } \\
\text { and significant pain and excessive } \\
\text { osteonecrosis of the jaw bones }\end{array}$ & $\begin{array}{l}\text { - Systemic treatment (antibiotics and analgesia), } \\
\text { - Surgical debridement or resection } \\
\text { of the necrotic bone, } \\
\text { - Antibacterial mouthwash, } \\
\text { - Follow-up visits every } 8 \text { weeks, } \\
\text { - Patient education }\end{array}$ \\
\hline
\end{tabular}


re osteoclast recruitment, reduction of osteoclast activity by inducing their apoptosis $[6,8]$. Thanks to their ability to bind with the bone matrix, the therapeutic effect of bisphosphonates may last up to 10 years after discontinuation of doses [4, 8]. Low-dose (oral) bisphosphonates such as alendronic acid, ibandronic acid and risedronic acid are used in majority of their indications described above [6]. However, ibandronic acid, pamidronic acid and zolendronic acid may also be administered intravenously (iv) once every 3 months and once a year, respectively, to treat the same illnesses. High doses of iv bisphosphonates, such as ibandronic acid, pamidronic acid and zoledronic acid are most commonly administered for prevention of metastasis to the bones in the course of multiple myeloma or cancer of the breast, lungs and prostate $[4,6,8]$.

Denosumab is a human monoclonal IgG2 antibody which inhibits the activation of osteoclasts and their precursors by selectively binding the receptor activator of nuclear factor k-B ligand (RANKL) on their surfaces [12]. This results in inhibition of maturation, function and longevity of osteoclasts, thus reducing bone resorption [2, 6]. Unlike bisphosphonates, denosumab does not bind with the bone matrix, thus its effect is minimal 12-24 months after discontinuation [8]. Low doses of denosumab are indicated for osteoporosis and prevention of bone metastasis (subcutaneous every 6 months), whereas high doses are administered for the treatment of bone metastases (subcutaneous every 4 weeks) [6].

Angiogenesis inhibitors are indicated in cancer treatment where they limit tumor and metastasis growth $[8,13]$. Of all the drugs in this group, anti-VEGF (vascular endothelial growth factor) and TKI (tyrosine kinase inhibitor) seem to correlate with higher risk of MRONJ [14-16]. Similarly to denosumab, angiogenesis inhibitors do not bind with bone matrix and are metabolized up to 20 days after discontinuation [6-7].

\section{Discussion}

Prevention of MRONJ should be based on qualification of patients to their appropriate MRONJ risk group, assessment of possible additional risk factors and formulating individual treatment recommendations [7]. Drug dose, duration of treatment and presence of additional MRONJ risk factors determine the patient's risk of MRONJ [6] [Table 2].

Up to $90 \%$ of MRONJ cases occur in oncological patients treated with high-dose antiresorptive drugs [6]. Osteonecrosis is usually caused by a local oral infection or injury of mucosa or bone [6-7]. The most common risk factor related to the oral cavity is tooth extraction (45-61\%), periodontal disease (10\%) and poorly fitted dentures $[3,7,17-18]$ [Table 3$]$. That is why cooperation between physicians and dentists is crucial in successful prevention of MRONJ [19-21]. Literature points out that MRONJ risk is lower among patients who were referred to a dentist and preventive procedures were performed [6, 22-23].

Table 2. Risk group assessment

\begin{tabular}{|c|c|c|c|}
\hline $\begin{array}{l}\text { RISK } \\
\text { GROUP }\end{array}$ & TREATMENT & $\begin{array}{c}\text { DURATION } \\
\text { OF } \\
\text { TREATMENT }\end{array}$ & $\begin{array}{c}\text { RISK } \\
\text { FACTORS } \\
\text { PRESENT?* }\end{array}$ \\
\hline $\begin{array}{c}\text { LOW } \\
\text { RISK } \\
\text { OF } \\
\text { MRONJ }\end{array}$ & $\begin{array}{l}\text { LOW-DOSE } \\
\text { low doses } \\
\text { of oral } \\
\text { bispho- } \\
\text { sphonates } \\
\text { Denosumab } \\
60 \text { mg every } \\
6 \text { months }\end{array}$ & $\begin{array}{l}\text { Treatment } \\
<3 \text { years }\end{array}$ & No \\
\hline $\begin{array}{c}\text { HIGH } \\
\text { RISK } \\
\text { OF } \\
\text { MRONJ }\end{array}$ & $\begin{array}{l}\text { LOW-DOSE } \\
\text { low doses } \\
\text { of oral } \\
\text { bispho- } \\
\text { sphonates } \\
\text { Denosumab } \\
60 \text { mg every } \\
6 \text { months }\end{array}$ & $\begin{array}{l}\text { Treatment } \\
>3 \text { years }\end{array}$ & Yes \\
\hline $\begin{array}{c}\text { HIGH } \\
\text { RISK } \\
\text { OF } \\
\text { MRONJ }\end{array}$ & $\begin{array}{l}\text { HIGH-DOSE } \\
\text { - high doses } \\
\text { of bisphos- } \\
\text { phonates iv } \\
\text { Denosumab } \\
120 \text { mg every } \\
4 \text { weeks }\end{array}$ & Irrelevant & Yes \\
\hline
\end{tabular}

* MRONJ risk factor: antiresorptive drugs, corticosteroids, chemotherapy, poor oral hygiene, periodontal disease, poorly fitted dentures, cigarette smoking, comorbidities (cancer, hematologic disease, immune system diseases, diabetes, anemia) 
Table 3. MRONJ local risk factors (according to AAOMS 2014)

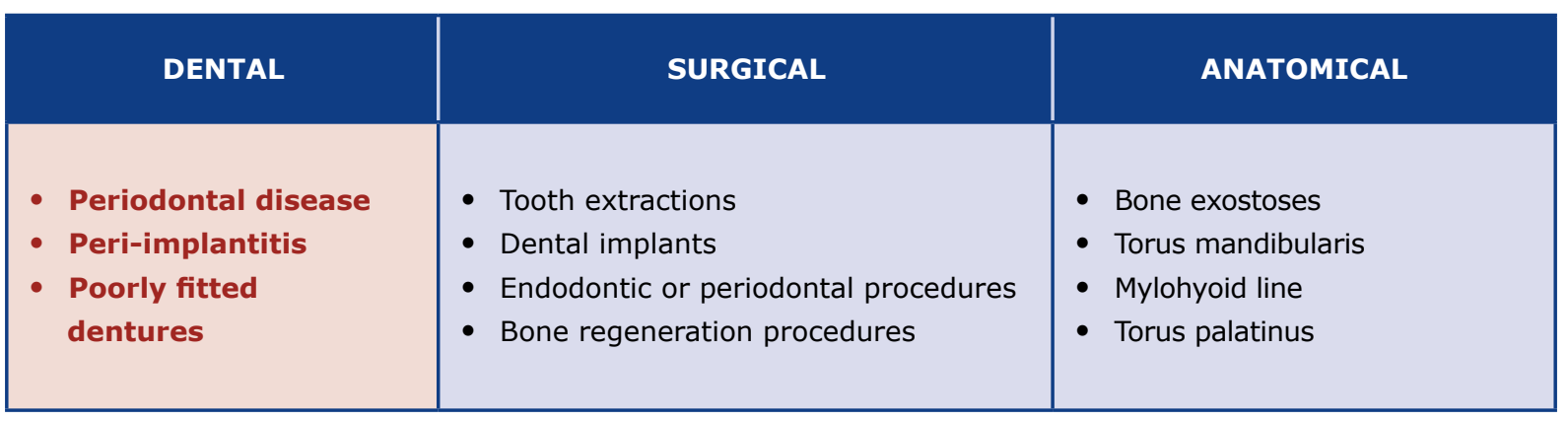

The specific preventive measures are dictated by assessing the patient's risk of MRONJ and by the stage of treatment with antiresorptive drugs $[6,21,23]$. Regardless of their MRONJ risk, all patients should be examined by a dentist and instructed about oral cavity hygiene [5-6, 19, 24]. In addition, the dentist should perform oral cavity sanation, perform periodontal treatment and check if the patient's dentures fit properly. The patient should be informed about the symptoms of MRONJ and the necessity of reporting them early [6].

After starting therapy with angiogenesis inhibitors or antiresorptive drugs, low-risk patients may undergo required and/or recommended dental treatment $[5-7,19,24]$.

A different approach is required for patients with high risk of MRONJ. A dental consultation is recommended before any surgical, periodontal or dental implant procedure. Information from the physician supervising the antiresorptive drug therapy is also required $[6,21]$.

Literature suggests that lack of cooperation between physicians and dentists is correlated with a higher incidence of MRONJ [25]. Dentists may be the first doctors who diagnose signs of MRONJ, and patients with such diagnosis need to be referred to a maxillofacial surgery center for specialized treatment [23]. Re- gardless of their risk of MRONJ, patients treated with antiresorptive drugs need to complete dental hygiene training and have a follow-up visit every 4 months [7].

\section{Conclusions}

Increased incidence of MRONJ forces a multi-disciplinary cooperation between dentists and the physicians who are treating the underlying illness. The dentist may be the first doctor who diagnoses signs of MRONJ and initiates treatment, thus increasing the likelihood of good outcome. Currently there is no defined MRONJ treatment algorithm, so it is critical to implement preventive measures before starting antiresorptive drug treatment. Patients who are qualified for treatment with angiogenesis inhibitors or antiresorptive drugs should undergo dental examination and undergo full oral sanation in order to reduce the risk of complications.

Acknowledgments: The authors thank dr Hanna Sobczak, Oral Surgeon, who kindly provided clinical advice and guidance.

Confllict of interests: None declared.

\section{References}

1. Marx RE. Pamidronate (Aredia) and zoledronate (Zometa) induced avascular necrosis of the jaws: a growing epidemic. J Oral Maxillofac Surg [Internet]. 2003 Sep;61(9):1115-7. Available from: https://linkinghub.elsevier.com/retrieve/pii/S0278239103007201

2. Ruggiero SL, Mehrotra B, Rosenberg TJ, Engroff SL. Osteonecrosis of the jaws associated with the use of bisphosphonates: a review of 63 cases. J Oral Maxillofac Surg [Internet]. 2004 May;62(5):527-34. Available from: https://linkinghub. elsevier.com/retrieve/pii/S0278239104001958

3. Ruggiero SL, Dodson TB, Assael LA, Landesberg R, Marx RE, Mehrotra B. American Association of Oral and Maxillofacial Surgeons Position Paper on Bisphosphonate-Related Osteonecrosis of the Jaws-2009 Update. J Oral Maxillofac Surg [Internet]. 2009 May;67(5):2-12. Available from: https://linkinghub.elsevier.com/retrieve/pii/S0278239109001153

4. Ruggiero SL, Dodson TB, Fantasia J, Goodday R, Aghaloo T, Mehrotra B, et al. American Association of Oral and Maxillofacial Surgeons Position Paper on Medication-Related Osteonecrosis of the Jaw - 2014 Update. J Oral Maxillofac Surg [Internet]. 2014 Oct;72(10):1938-56. Available from: https://linkinghub.elsevier.com/retrieve/pii/S0278239114004637 
5. Muthukrishnan A, Bijai Kumar L, Ramalingam G. Medication-related osteonecrosis of the jaw: a dentist's nightmare. BMJ Case Rep [Internet]. 2016 Apr 6;2016:bcr2016214626. Available from: http://casereports.bmj.com/lookup/doi/10.1136/bcr-2016-214626

6. Nicolatou-Galitis O, Schiødt M, Mendes RA, Ripamonti C, Hope S, Drudge-Coates L, et al. Medication-related osteonecrosis of the jaw: definition and best practice for prevention, diagnosis, and treatment. Oral Surg Oral Med Oral Pathol Oral Radiol [Internet]. 2019 Feb;127(2):117-35. Available from: https://linkinghub.elsevier.com/retrieve/pii/S2212440318311933

7. Di Fede O, Panzarella V, Mauceri R, Fusco V, Bedogni A, Lo Muzio L, et al. The Dental Management of Patients at Risk of Medication-Related Osteonecrosis of the Jaw: New Paradigm of Primary Prevention. Biomed Res Int [Internet]. 2018 Sep 16;2018:1-10. Available from: https://www.hindawi.com/journals/bmri/2018/2684924/

8. Eguia A, Bagán-Debón L, Cardona F. Review and update on drugs related to the development of osteonecrosis of the jaw. Med Oral Patol Oral y Cir Bucal [Internet]. 2020;25(1):e71-83. Available from: http://www.medicinaoral.com/medoralfree01/aop/23191.pdf

9. Dunphy L, Salzano G, Gerber B, Graystone J. Medication-related osteonecrosis (MRONJ) of the mandible and maxilla. BMJ Case Rep [Internet]. 2020 Jan 5;13(1):e224455. Available from: http://casereports.bmj.com/lookup/doi/10.1136/bcr-2018-224455

10. Beth-Tasdogan NH, Mayer B, Hussein H, Zolk O. Interventions for managing medication-related osteonecrosis of the jaw. Cochrane Database Syst Rev [Internet]. 2017 Oct 6; Available from: http://doi.wiley.com/10.1002/14651858.CD012432.pub2

11. McGowan K, McGowan T, Ivanovski S. Risk factors for medication-related osteonecrosis of the jaws: A systematic review. Oral Dis [Internet]. 2018 May;24(4):527-36. Available from: http://doi.wiley.com/10.1111/odi.12708

12. Deeks ED. Denosumab: A Review in Postmenopausal Osteoporosis. Drugs Aging [Internet]. 2018 Feb 12;35(2):163-73. Available from: http://link.springer.com/10.1007/s40266-018-0525-7

13. Mander K, Finnie J. Tumour angiogenesis, anti-angiogenic therapy and chemotherapeutic resistance. Aust Vet J [Internet]. 2018 Oct;96(10):371-8. Available from: http://doi.wiley.com/10.1111/avj.12747

14. Otto S, Pautke C, Van den Wyngaert T, Niepel D, Schiødt M. Medication-related osteonecrosis of the jaw: Prevention, diagnosis and management in patients with cancer and bone metastases. Cancer Treat Rev [Internet]. 2018 Sep;69(February):177-87. Available from: https://linkinghub.elsevier.com/retrieve/pii/S0305737218301014

15. Jacobsen C, Zemann W, Obwegeser JA, Grätz KW, Metzler P. The phosphorous necrosis of the jaws and what can we learn from the past: a comparison of "phossy" and "bisphossy" jaw. Oral Maxillofac Surg [Internet]. 2014 Mar 28;18(1):31-7. Available from: http://link.springer.com/10.1007/s10006-012-0376-z

16. Khan AA, Morrison A, Hanley DA, Felsenberg D, McCauley LK, O'Ryan F, et al. Diagnosis and Management of Osteonecrosis of the Jaw: A Systematic Review and International Consensus. J Bone Miner Res [Internet]. 2015 Jan;30(1):3-23. Available from: http://doi.wiley.com/10.1002/jbmr.2405

17. Göllner M, Holst S, Fenner M, Schmitt J. Prosthodontic treatment of a patient with bisphosphonate-induced osteonecrosis of the jaw using a removable dental prosthesis with a heat-polymerized resilient liner: A clinical report. J Prosthet Dent [Internet]. 2010 Apr;103(4):196-201. Available from: https://linkinghub.elsevier.com/retrieve/pii/S0022391310000521

18. Hasegawa Y, Kawabe M, Kimura H, Kurita K, Fukuta J, Urade M. Influence of dentures in the initial occurrence site on the prognosis of bisphosphonate-related osteonecrosis of the jaws: a retrospective study. Oral Surg Oral Med Oral Pathol Oral Radiol [Internet]. 2012 Sep;114(3):318-24. Available from: https://linkinghub.elsevier.com/retrieve/pii/S2212440312003136

19. Campisi G, Fedele S, Fusco V, Pizzo G, Di Fede O, Bedogni A. Epidemiology, clinical manifestations, risk reduction and treatment strategies of jaw osteonecrosis in cancer patients exposed to antiresorptive agents. Futur Oncol [Internet]. 2014 Feb;10(2):257-75. Available from: https://www.futuremedicine.com/doi/10.2217/fon.13.211

20. Yarom N, Shapiro CL, Peterson DE, Van Poznak CH, Bohlke K, Ruggiero SL, et al. Medication-Related Osteonecrosis of the Jaw: MASCC/ISOO/ASCO Clinical Practice Guideline. J Clin Oncol [Internet]. 2019 Sep 1;37(25):2270-90. Available from: http://ascopubs.org/doi/10.1200/JCO.19.01186

21. Yoneda T, Hagino H, Sugimoto T, Ohta H, Takahashi S, Soen S, et al. Antiresorptive agent-related osteonecrosis of the jaw: Position Paper 2017 of the Japanese Allied Committee on Osteonecrosis of the Jaw. J Bone Miner Metab [Internet]. 2017 Jan 29;35(1):6-19. Available from: http://link.springer.com/10.1007/s00774-016-0810-7

22. Hellstein JW, Adler RA, Edwards B, Jacobsen PL, Kalmar JR, Koka S, et al. Managing the care of patients receiving antiresorptive therapy for prevention and treatment of osteoporosis. J Am Dent Assoc [Internet]. 2011 Nov;142(11):1243-51. Available from: https://linkinghub.elsevier.com/retrieve/pii/S0002817714628142

23. Rosella D, Papi P, Giardino R, Cicalini E, Piccoli L, Pompa G. Medication-related osteonecrosis of the jaw: Clinical and practical guidelines. J Int Soc Prev Community Dent [Internet]. 2016;6(2):97. Available from: http://www.jispcd.org/text.asp?2016/6/2/97/178742

24. Coleman R, Body JJ, Aapro M, Hadji P, Herrstedt J. Bone health in cancer patients: ESMO Clinical Practice Guidelines. Ann Oncol [Internet]. 2014 Sep;25:iii124-37. Available from: https://linkinghub.elsevier.com/retrieve/pii/S0923753419340785

25. Taguchi A, Shiraki M, Sugimoto T, Ohta H, Soen S. Lack of cooperation between physicians and dentists during osteoporosis treatment may increase fractures and osteonecrosis of the jaw. Curr Med Res Opin [Internet]. 2016 Jul 2;32(7):1261-8. Available from: $\underline{\text { http://www.tandfonline.com/doi/full/10.1185/03007995.2016.1170005 }}$ 